\title{
Trends of teenage pregnancy in Brazil, 2000-2011
}

\author{
Raquel Ferreira Vaz ${ }^{1}$, Denise Leite Maia Monteiro²*, Nádia Cristina Pinheiro Rodrigues ${ }^{3}$ \\ ${ }^{1}$ Graduate degree in Family Health; MD from Centro Universitário Serra dos Órgãos (Unifeso) - Physician at PSF, Candeias, MG, Brazi \\ ${ }^{2} \mathrm{PhD}$ - Adjunct Professor, Universidade Estadual do Rio de Janeiro (Uerj) and Full Professor, Unifeso, Rio de Janeiro, RJ, Brazil \\ ${ }^{3}$ PhD - Adjunct Professor, Uerj. Researcher, Escola Nacional de Saúde Pública (ENSP), Fundação Oswaldo Cruz (Fiocruz), Rio de Janeiro, RJ, Brazi
}

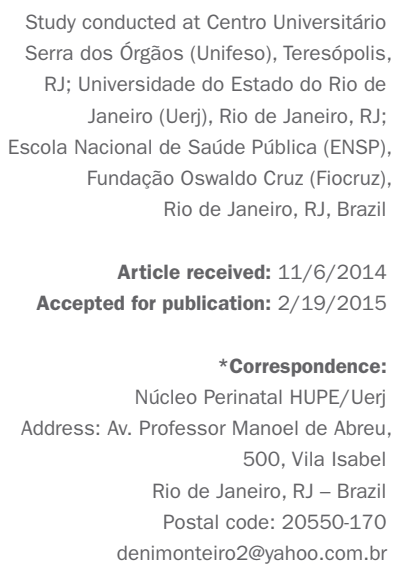

Study conducted at Centro Universitário Serra dos Órgãos (Unifeso), Teresópolis, RJ; Universidade do Estado do Rio de Janeiro (Uerj), Rio de Janeiro, RJ; Escola Nacional de Saúde Pública (ENSP), Fundação Oswaldo Cruz (Fiocruz), Rio de Janeiro, RJ, Brazil

Article received: $11 / 6 / 2014$ Accepted for publication: 2/19/2015

*Correspondence: Núcleo Perinatal HUPE/Uerj Address: Av. Professor Manoel de Abreu, 500 , Vila Isabel Rio de Janeiro, RJ - Brazi Postal code: 20550-170 denimonteiro2@yahoo.com.br

\section{SUMMARY}

Objective: To evaluate the frequency of teenage pregnancy in Brazil, from 2000 to 2011, in all five Brazilian macroregions and age groups (10-14 and 15-19 years), correlating it with the human development index (HDI).

Method: Descriptive epidemiological study, with cross-sectional design, performed by searching the database of the National Health System (Datasus), using information from the Information System (Sinasc).

Results: There was a decrease in the percentage of live births (LB) from teenage mothers (10-19 years) in Brazil (23.5\% in 2000 to $19.2 \%$ in 2011). This reduction was observed in all Brazilian macroregions in the group of mothers aged 15 to 19 years. The number of LB increased by $5.0 \%$ among mothers aged $10-14$ years (increase in the North and Northeast and decline in the other macroregions). The proportion of LB shows an inversely proportional trend to HDI score, with the Southeast having the highest HDI and the lowest proportion of LB to teenage mothers in the country.

Conclusion: Brazil shows a decline in the percentage of LB to adolescent mothers, tending to be inversely related to HDI score. It is important to empower strategies to address the problem, so that teenage pregnancy is seen as a personal decision rather than the result of a lack of policies targeting adolescent health.

Keywords: pregnancy in adolescence, prevalence, epidemiology, social conditions, adolescent, human development.

\section{INTRODUCTION}

According to the World Health Organization (WHO) adolescence is the period between 10 and 19 years old; ${ }^{1}$ it is a phase of intense physical, biological and emotional changes, marked by affective relationships and often the start of sexual experiences.

Factors related to early pregnancy most often cited include: accelerated sexual maturation, early onset of sexual life, fragile family unit, and uncontrolled urbanization process with significant changes in lifestyle. ${ }^{2}$ Teenage pregnancy tends to be inversely proportional to the level of education. Many of these young women remain outside the education system for several years, suggesting an association between early pregnancy and delay or interruption of formal education. ${ }^{3-6}$

Heilborn et al. (2002) call attention to the fact that for a long time, adolescence was the ideal time in life to have a child. The redefinitions of social expectations placed on young people nowadays and the current possibility of experiencing sexuality not linked to reproduction turned pregnancy into lost opportunities in youth. ${ }^{7}$

Indeed, teenage pregnancy brings about profound changes in the lives of these young women, especially in terms of emotional, educational, social and economic aspects. ${ }^{8}$ When psychological and social indicators related to pregnancy are evaluated, the downside for adolescents can be clearly noticed. Particularly in the case of single mothers, it triggers and extends a series of events that disrupt the harmony of the adolescent's personal development and her family life. ${ }^{3,4,6,8}$

For these reasons, teenage pregnancy has been the object of concern of government agencies, health and education professionals, and the entire society. Many programs to reduce its prevalence have been deployed in the last two decades. ${ }^{9}$ Although fertility rates in this age group, contrary to what is stated in many studies, are declining 
globally, about 18 million girls aged under 20 years give birth each year, ${ }^{10}$ with a frequency of live births to teenage mothers that varies from country to country. ${ }^{5}$

However, teenage pregnancy is not always viewed negatively. Gontijo and Medeiros discussed a number of studies dealing with perceptions of pregnancy among adolescents in personal and social risk, identifying that, in these groups, pregnancy can be viewed positively because motherhood takes on a central role, offering new possibilities for social recognition and action. ${ }^{11}$

Regarding the biological aspect, Mathias et al. concluded that all adolescents at the time of pregnancy reach similar biological and endocrine maturity, as well as obstetrical performance. Progression that is less satisfactory for early adolescents (age below 15 years) is due to unfavorable socioeconomic conditions associated with insufficient control of prenatal care. ${ }^{12}$

The great importance of teenage pregnancy lies in its social aspects, not in biological and/or medical issues, as once believed, for it is still an unresolved problem in developing and also in some developed countries. ${ }^{13}$ The main associated factors are: low education of the adolescent, maternal history of teenage pregnancy, lack of previous gynecological appointments and lack of access to contraceptive methods. ${ }^{3}$

Teenage pregnancy is a gateway to poverty because it leads to decrease in the array of social and economic opportunities, including access to school. Thus, it is a complex and multifactorial phenomenon, encompassing economic, educational and behavioral aspects. ${ }^{3,10,14}$

In Brazil, a reduction of teenage pregnancy has been observed since 2000. As the frequency of live births to teenage mothers also varies between regions in the same country, being a reflection of economic conditions, cultural differences and access to health services and contraceptive methods, ${ }^{5}$ we prepared this study aimed at assessing the frequency of teenage pregnancy in Brazil, in the period from 2000 to 2011, in the five macroregions of the country, focusing on two age groups (10-14 and 15-19 years), correlating the above with the human development index (HDI) of each region.

\section{Method}

This cross-sectional, descriptive study was conducted with data from the Brazilian Live Births Information System (Sinasc) of the Unified Health System (Datasus), a system run by the Department of Health Situation Analysis, under the Health Surveillance Department, in conjunction with the State and Municipal Health Departments. These bodies gather all statements of live birth (SLB) issued by health facilities and registry offices (in the case of home birth) and enter the information contained therein in the Sinasc system..$^{15}$

Overall, the state health departments send their databases to the Ministry of Health, which can only consider the National Base complete when all states send their data. Then, consolidation is made, including redistribution of data by place of residence, which is the traditional way to present live birth data. The SINASC collects about 30 variables of SLB, made available for data analysis over the internet. To conduct this study, we used the following variables: birth according to the mother's place of residence, birth by region in Brazil, year of birth, and mother's age. ${ }^{15}$

The study population consisted of all women who had LB in the years 2000 to 2011 in the five macroregions of Brazil. We sought information on the total number of LB by macroregion, as well as within the age groups 10 14 and 15-19, to calculate the percentage of LB to teenage mothers. Of the total $\mathrm{LB}$, those recorded as age of the mother unknown (56,564 LB in 2000-2005 and 1,048 LB in 2006-2011) were excluded. The association between the frequency of teenage pregnancy and the human development index (HDI) of each region was also analyzed. HDI is a summary measure of long-term progress in three basic dimensions of human development: income, education and health. ${ }^{16}$ The 2010 census provides the HDI score by state/municipality, and therefore we calculated the average HDI for states weighted by population to obtain the HDI score of each region.

Absolute and relative frequencies of the number of LB by mother's age group and year of occurrence were calculated. The percentage increase or decrease of 20002011 was calculated using the expression: [(\% of LB in 2011 - \% of LB in 2000)/\% of LB in 2000] $\times 100$. Graphic models were used to describe the results.

The theoretical basis for writing the article constituted on review of medical literature available through the search of publications in PubMed, SciELO, Lilacs and academic Google using as keywords: "pregnancy in adolescence", "prevalence", "epidemiology", "social conditions", "human development", "gravidez na adolescência", "prevalência", "epidemiologia”, "condições sociais" and "desenvolvimento humano". The articles were assessed by two reviewers, who selected a total of 26 references, including official publications available on the internet.

Since these are databases in the public domain, submitting the project to the ethics committee of the institution was not required. 


\section{Results}

By analyzing the number of LB to mothers aged 10 to 14 years in the period from 2000 to 2011, an increase was found in the Northern and Northeastern macroregions (12.5\% and $13.4 \%$, respectively), while other Brazilian macroregions showed decline (3.6\% in the Southeast; $13.0 \%$ in the South; and $14.3 \%$ in the Midwest).

As for the number of LB to mothers aged 15 to 19 years in the same period, a reduction was seen in all Brazilian macroregions $(15.0 \%$ in the North; $17.6 \%$ in the Northeast; $19.9 \%$ in the South; $22.0 \%$ in the Southeast; and $27.9 \%$ in the Midwest) (Figure 1).

In Brazil as a whole, there was an increase of $5.0 \%$ in the number of LB to mothers aged from 10 to 14 years, and a $19.1 \%$ decline among mothers in the age range from 15 to 19 years.

Table 1 shows the distribution of LB by mother's age, and the number of records with mother's age unknown, indicating decline in the percentage of LB to teenage mothers (10 to 19 years) in Brazil comparing 2000 with
2011 (from $23.5 \%$ in 2000 to $19.2 \%$ in 2011) and improved data quality, since the number of mothers whose age is ignored declined, especially after 2005. Such decline in the number of $\mathrm{LB}$ was boosted by mothers in the age range from 15 to 19 years in all of the Brazilian macroregions.

Regarding the HDI of 2010 by macroregion, the Southeast had the highest score (0.76), followed by the South and the Midwest (0.75), the North (0.67) and the Northeast (0.66) of Brazil. The proportion of LB to teenage mothers in the Southeast is the lowest in the country, which is the macroregion with the highest HDI. Thus, the proportion of LB tends to be inversely proportional to the HDI score (Table 2).

\section{Discussion}

This study points out the relationship between teenage pregnancy and social, educational, economic and cultural factors in the population, showing that these are increasingly active in the decision to postpone pregnancy. The data obtained revealed that in Brazilian macroregions

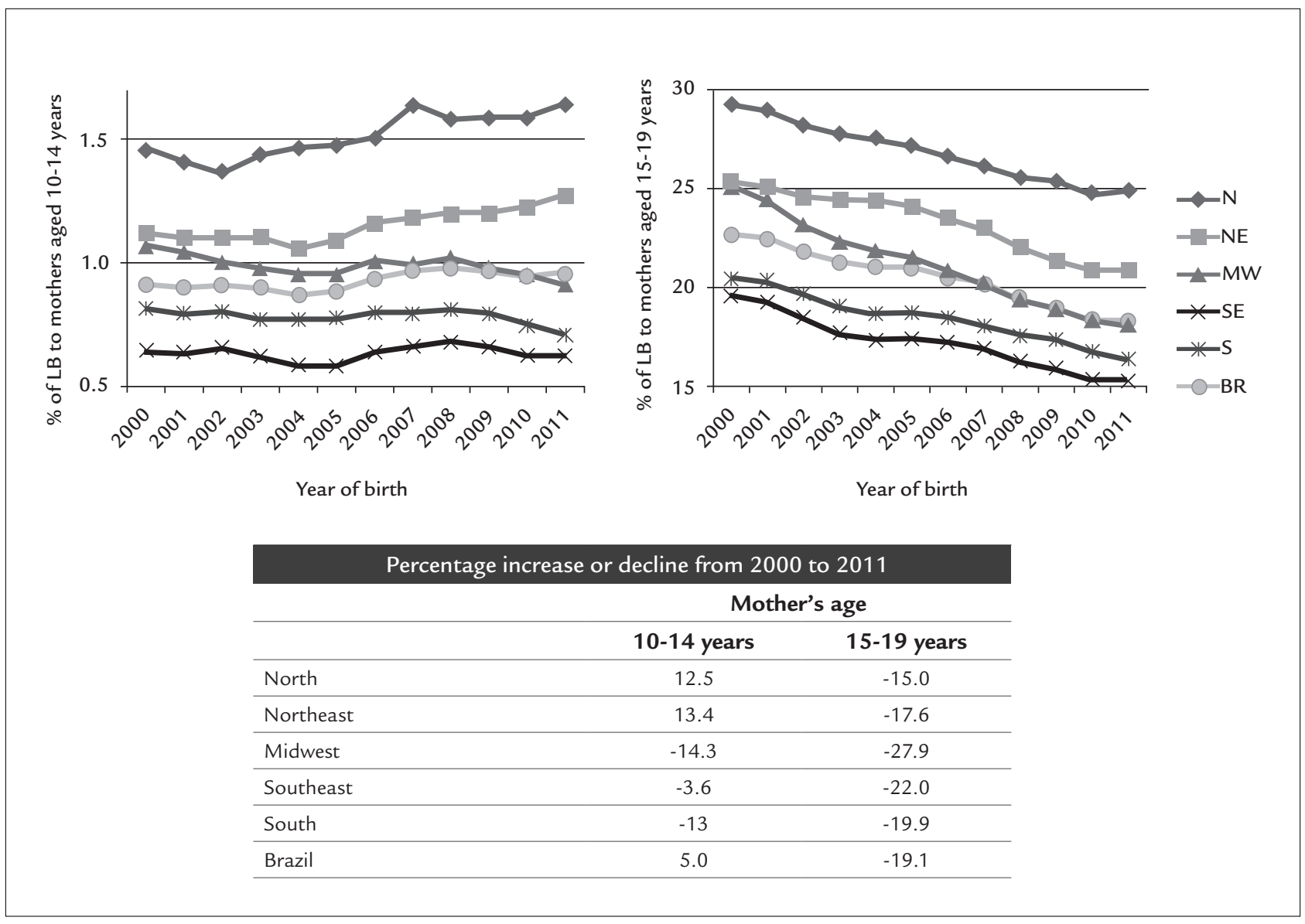

FIGURE 1 Relationship between the percentage of live births to mothers in the age ranges 10-14 and 15-19 years in the period 2000-2011 by macroregion. 
TABLE 1 Distribution of live births according to maternal age.

\begin{tabular}{|c|c|c|c|c|c|c|c|c|c|c|c|c|}
\hline Age & 2000 & 2001 & 2002 & 2003 & 2004 & 2005 & 2006 & 2007 & 2008 & 2009 & 2010 & 2011 \\
\hline \multicolumn{13}{|c|}{ Northern region } \\
\hline 10 to 14 & 4209 & 4194 & 4116 & 4461 & 4514 & 4624 & 4773 & 5101 & 5086 & 4929 & 4864 & 5136 \\
\hline 15 to 19 & 84552 & 86321 & 84923 & 86245 & 84959 & 85255 & 84474 & 81479 & 82328 & 78837 & 75829 & 77971 \\
\hline Ignored & 1566 & 1446 & 513 & 659 & 557 & 920 & 5 & 4 & 0 & 3 & 13 & 4 \\
\hline Total LB & 290708 & 299388 & 301208 & 311335 & 309136 & 314858 & 317493 & 311813 & 321998 & 310726 & 306422 & 313745 \\
\hline \multicolumn{13}{|c|}{ Northeastern region } \\
\hline 10 to 14 & 10247 & 10277 & 10193 & 10257 & 9604 & 10047 & 10287 & 10389 & 10621 & 10385 & 10292 & 10811 \\
\hline 15 to 19 & 231791 & 233959 & 227274 & 226102 & 221395 & 222482 & 208291 & 201889 & 195585 & 184903 & 174929 & 177593 \\
\hline Ignored & 11277 & 9922 & 4822 & 3619 & 3108 & 2670 & 35 & 27 & 21 & 18 & 31 & 10 \\
\hline Total LB & 926104 & 942141 & 929717 & 930145 & 910775 & 924983 & 887306 & 878588 & 888268 & 865098 & 841160 & 851004 \\
\hline \multicolumn{13}{|c|}{ Midwestern region } \\
\hline 10 to 14 & 2470 & 2374 & 2277 & 2213 & 2198 & 2209 & 2232 & 2133 & 2264 & 2163 & 2100 & 2069 \\
\hline 15 to 19 & 58199 & 55477 & 52565 & 50392 & 50161 & 49709 & 46284 & 43535 & 43246 & 41567 & 40525 & 41013 \\
\hline Ignored & 932 & 466 & 296 & 201 & 296 & 189 & 38 & 8 & 80 & 53 & 101 & 44 \\
\hline Total LB & 232705 & 227515 & 227193 & 225965 & 229596 & 231307 & 221672 & 215260 & 222658 & 220168 & 220788 & 226577 \\
\hline \multicolumn{13}{|c|}{ Southeastern region } \\
\hline 10 to 14 & 8375 & 7795 & 7825 & 7312 & 6894 & 6837 & 7288 & 7453 & 7705 & 7413 & 7028 & 7087 \\
\hline 15 to 19 & 255001 & 236617 & 220729 & 208866 & 204148 & 203667 & 196111 & 189945 & 184178 & 178087 & 172266 & 174613 \\
\hline Ignored & 3997 & 2445 & 1595 & 1175 & 925 & 979 & 665 & 293 & 35 & 18 & 28 & 34 \\
\hline Total LB & 1306235 & 1230473 & 1195168 & 1181131 & 1178915 & 1171841 & 1139395 & 1122809 & 1130407 & 1119231 & 1123593 & 1143741 \\
\hline \multicolumn{13}{|c|}{ Southern region } \\
\hline 10 to 14 & 3672 & 3291 & 3253 & 2996 & 3066 & 3035 & 3030 & 2887 & 3002 & 2917 & 2765 & 2682 \\
\hline 15 to 19 & 92021 & 84581 & 79946 & 74201 & 74351 & 73272 & 70110 & 65561 & 65223 & 63565 & 62032 & 61913 \\
\hline Ignored & 799 & 457 & 240 & 191 & 175 & 127 & 30 & 9 & 7 & 8 & 21 & 5 \\
\hline Total LB & 451009 & 415957 & 406116 & 389675 & 398126 & 392107 & 379062 & 362858 & 371497 & 366358 & 369905 & 378093 \\
\hline \multicolumn{13}{|l|}{ Brazil } \\
\hline $10-14$ & 28973 & 27931 & 27664 & 27239 & 26276 & 26752 & 27610 & 27963 & 28678 & 27807 & 27049 & 27785 \\
\hline 15-19 & 721564 & 696955 & 665437 & 645806 & 635014 & 634385 & 605270 & 582409 & 570560 & 546959 & 525581 & 533103 \\
\hline Ignored & 18571 & 14736 & 7466 & 5845 & 5061 & 4885 & 173 & 341 & 143 & 100 & 194 & 97 \\
\hline Total LB & 3206761 & 3115474 & 3059402 & 3038251 & 3026548 & 3035096 & 2944928 & 2891328 & 2934828 & 2881581 & 2861868 & 2913160 \\
\hline
\end{tabular}

TABLE 2 Relationship between the average percentage of live births to mothers in the age ranges 10-14 and 15-19 years in 2010 and HDI score (2010) by macroregion.

\begin{tabular}{llll} 
Macroregions & LB-10-14 years (2010) \% & LB-15-19 years (2010) \% & HDI 2010 \\
\hline Southeast & 0.63 & 15.33 & 0.76 \\
\hline South & 0.75 & 16.77 & 0.75 \\
\hline Midwest & 0.95 & 18.36 & 0.75 \\
\hline North & 1.59 & 24.75 & 0.67 \\
\hline Northeast & 1.22 & 20.80 & 0.66 \\
\hline
\end{tabular}


with higher HDI (South, Southeast and Midwest) there are lower rates of LB to adolescent mothers, which can be correlated as a possible marker of development.

Increasing education leads to increased use of contraceptive methods, a trend that first sexual intercourse does not happen early without proper protection, and the value of forming smaller families. ${ }^{17}$

Corroborating these data, Duarte et al. observed, in Santo André (greater area of São Paulo), that the areas with the worst social exclusion contained the largest number of live births to teenagers, concentrating the largest number of adolescents with less education and low birth weight babies. ${ }^{5}$

Likewise, Martinez et al. showed that teenage pregnancy occurs most often in environments punctuated by limited opportunities and fewer options in life. This conclusion was based on the observation that municipalities with low HDI and higher incidence of poverty are those with the highest percentages of teenage pregnancy. In addition, these percentages are associated with low levels of education, noting that the literature shows that interruptions in the educational path prior to pregnancy perpetuate the status of social exclusion for many generations among the women from the same family. ${ }^{4,6}$

Currently, another major concern is the high rate of recurrence of teenage pregnancy. Silva et al. ${ }^{20}$ describe as the main factors associated with recurrence of teenage pregnancy: first sexual intercourse before the age of 15 years, first pregnancy before the age of 16 , stable relationship with a same partner, not taking care of the children, and family income below the minimum wage, demonstrating a special association between reproductive and socioeconomic factors. ${ }^{18}$ This concern is even more relevant considering that at each new pregnancy, the likelihood of that the adolescent will finish school, have a stable job and become economically self-sufficient decreases. ${ }^{19}$ In Rio de Janeiro, the rate of repeated pregnancy in the second half of adolescence (between 15 and 19 years) was $13.5 \%$, while in São Paulo $15.3 \%$ of pregnant women were multigest. These young women have poorer education, lower adherence to prenatal care, reduced weight gain, shorter intervals between births, and less stable marriages compared to adults or pregnant women of the same age in their functional debut. ${ }^{21}$

The Ministry of Health ( $\mathrm{MH})$ estimates that approximately one million teenagers become pregnant every year in Brazil. Of each five newborns registered in vital records in 2007 , one was born to a teenage mother (20.1\%), an approximate contingent of 553,548 children, of which $19.3 \%$ were born to mothers aged 15 to 19 years, and $0.8 \%$ to mothers in the age range from 10 to 14 years (IBGE, 2007). ${ }^{22}$
Fertility among adolescents can be considered one of the best health quality indicators in a modern country. In developing countries, there is, in terms of age, an expectation to follow the sexual behavior patterns of the developed countries without the necessary State counterpart to provide adequate education, as well as the due levels of service for attention and care that are absolutely crucial. ${ }^{23}$

In industrialized Europe, a study of women aged 15 years or older showed that Italy and the Netherlands have the lowest rate of teenage mothers (2.3\%). ${ }^{24}$ In Eastern Europe, the proportions are higher for Georgia (21\%), Bulgaria $(20.5 \%)$ and Ukraine (19.5\%). ${ }^{25}$

The teenage birth rates in the USA fell by $37 \%$, declining from 61.8/1,000 in 1991 to 39.1/1,000 in 2009, with largest frequencies among Hispanic (70.1) and Black (59.9), and lowest among Caucasian adolescents (25.6). The rate of teenage pregnancy in the US is higher than in Canada $(13.7 / 1,000) .{ }^{26}$

\section{Conclusion}

As for Brazil, the present study showed a decline in the percentage of LB to teenage mothers $(23.5 \%$ in 2000 to $19.2 \%$ in 2011), caused by decrease in the percentage of LB to mothers in the age range from 15 to 19 years, in contrast with a discreet increase among girls younger than 15 years during the study period.

The results of this study may be underestimated because the available data comprise information of pregnancies carried to term with live births, not taking into account all the others that had unfavorable outcomes, such as pregnancy complications or abortion. A limitation of this study was the proportion of mothers with unknown age, since the authors cannot know if there were teenagers in this group, which may not have been counted. However, over the years, there was significant reduction of mothers with unknown age, particularly after 2005, which indicates an improvement in data quality.

Proper prenatal care to pregnant adolescents can promote early diagnosis and correct risk factors for low birth weight, especially among the younger pregnant girls. ${ }^{13}$ It is very important that our teenagers are able to improve their social, economic and cultural situation; that they are encouraged to study, increasing prospects for a better future; that they are also encouraged to adopt a more positive attitude toward sexuality and family planning; and receive assistance that provides information on manners to practice safe and responsible sex. The availability of care centers aimed at promoting adolescent health, family planning and prevention of sexually transmitted diseases, with a multidisciplinary medical team could lead to reduced risk of pregnancy in adolescence. ${ }^{8}$ 
Teenage pregnancy can lead to repercussions within society and the girls themselves (marking and affecting their entire life). From the standpoint of the community and the government, this phenomenon is strongly associated with low education levels and negative impact on potential economic rise, triggering problems and disadvantages derived from early motherhood. Therefore, despite statistics showing a small decline in frequency, there is no doubt that strengthening strategies to address the problem is necessary, so that teenage pregnancy can be a woman's own decision, and not a result of lack of public policies targeted to adolescents.

\section{Resumo}

Tendências da gravidez na adolescência no Brasil, 2000-2011

Objetivo: avaliar a frequência da gravidez na adolescência no Brasil, no período entre 2000 e 2011, nas cinco diferentes regiões brasileiras e por faixas de idade (10 a 14 e 15 a 19 anos), correlacionando com o índice de desenvolvimento humano (IDH).

Método: estudo epidemiológico, descritivo, com desenho transversal, realizado por busca no banco de dados do sistema único de saúde (Datasus), utilizando informações do Sistema de Informação sobre Nascidos Vivos (Sinasc).

Resultados: ocorreu queda do percentual de nascidos vivos (NV) de mães adolescentes (10 a 19 anos) no Brasil (23,5\% em 2000 para 19,2\% em 2011). Essa redução foi notada em todas as regiões brasileiras na parcela de mães entre 15 e 19 anos. O número de NV aumentou 5,0\% entre mães de 10 a 14 anos (incremento no Norte e Nordeste e redução nas demais regiões). A proporção de NV mostra tendência inversamente proporcional ao IDH, tendo o Sudeste o maior IDH e a menor proporção de NV de mães adolescentes no país. Conclusão: o Brasil apresenta declínio do percentual de NV de mães adolescentes, com tendência a estar inversamente relacionado ao IDH. É importante intensificar as estratégias de abordagem do problema, a fim de que a gravidez na adolescência seja uma decisão própria e não consequência da falta de políticas públicas direcionadas ao adolescente.

Palavras-chave: gravidez na adolescência, prevalência, epidemiologia, condições sociais, adolescente, desenvolvimento humano.

\section{RefEREnCES}

1. World Health Organization. Young people's health: a challenge for society. Report of a WHO Study Group on Young People and Health for All by the Year 2000. Geneva: World Health Organization, 1986.
2. Coates V, Sant'Anna JC. Gravidez na adolescência. In: Gejer D, Reato LFN Sexualidade e saúde reprodutiva na adolescência. São Paulo: Atheneu, 2001. p.71-84.

3. Amorim MMR, Lima LA, Lopes CV, Araújo DKL, Silva JGG, César LC, et al. Risk factors for pregnancy in adolescence in a teaching maternity in Paraíba: a case-control study. Rev Bras Ginec Obstet. 2009; 31(8):404-10.

4. Almeida MCC, Aquino EML. The role of education level in the intergenerational pattern of adolescent pregnancy in Brazil. Int Perspect Sex Reprod Health. 2009; 35(3):139-46.

5. Duarte CM, Nascimento VB, Akerman M. Gravidez na adolescência e exclusão social: análise de disparidadesintra-urbanas. Rev Panam Salud Publica. 2006; 19(4):236-43

6. Martinez EZ, Roza DL, Caccia-Bava MC, Achcar JA, Dal-Fabbro AL. Teenage pregnancy rates and socioeconomic characteristics of municipalities in São Paulo State, Southeast Brazil: a spatial analysis. Cad Saúde Pública. 2011; 27(5):855-67

7. Heilborn M, Salem T, Rohden F, Brandão E, Knauth D, Víctora C, et al. Aproximações socioantropológicas sobre a gravidez na adolescência. Horiz Antropol. 2002; 8(17):3-45.

8. Federação Brasileira de Ginecologia e Obstetrícia (FEBRASGO). Gestação na adolescência: aspectos atuais. In: Manual de orientação infanto puberal. São Paulo: FEBRASGO, 2010. p.171-9.

9. Swierzewski SJ. Overview, consequences of teenage pregnancy. [cited 2013 Jan 10]. Available from: http://www.womenshealthchannel.com/ teenpregnancy/index.shtml.

10. World Health Organization (WHO). Adolescent pregnancy: fact sheet. 2012. [cited 2012 Sep 15]. Available from: http://www.who.int/mediacentre/ factsheets/fs364/en/index.html.

11. Gontijo DT, Medeiros M. A gravidez/maternidade e adolescentes em situação de risco social e pessoal: algumas considerações. Rev Eletrônica Enf. 2004; 3(6):394-9.

12. Mathias L, Nestarez JE, Kanas M, Neme B. Gravidez na adolescência. IV Idade limite de risco reprodutivo entre adolescentes. J Bras Ginecol. 1985; 95(4):141-3.

13. Pinto e Silva JL, Surita FGC. Gravidez na adolescência: situação atual. Rev Bras Ginecol Obstet. 2012; 34(8):347-50.

14. Chalem E, Mitsuhiro SS, Ferri CP, Barros MCM, Guinsburg R, Laranjeira R. Teenage pregnancy: Behavioral and socio-demographic profile of an urban Brazilian population. Cad Saúde Pública. 2007; 23(1):177-86.

15. Ministério da Saúde/DATASUS. Departamento de Informática do SUS Informações de Saúde - Estatísticas vitais. [cited 2013 Nov 5]. Available from: http://tabnet.datasus.gov.br/ cgi/deftohtm.exe?sinasc/cnv/nvuf.def.

16. PNUD. Programa das Nações Unidas para o Desenvolvimento. Desenvolvimento Humano e IDH. [cited 2013 Oct 18]. Available from: http://www.pnud.org.br/atlas/ranking/Ranking-IDHM-UF-2010.aspx.

17. McIntyre SH, Newburn-Cook CV, O'Brien B, Demianczuk NN. Effect of older maternal age on the risk of spontaneous preterm labor: a populationbased study. Health Care Women Int. 2009; 30(8):670-89.

18. Silva AA, Coutinho IC, Katz L, Souza ASR. Fatores associados à recorrência da gravidez na adolescência em uma maternidade escola: estudo casocontrole. Cad Saúde Pública. 2013; 29:496-506.

19. Lewis LN, Doherty DA, Hickey M, Skinner SR. Predictors of sexual intercourse and rapid-repeat pregnancy among teenage mothers: an Australian prospective longitudinal study. Med J Aust. 2010; 193:338-42.

20. Silva KS, Rozenberg R, Bonan C, Chuva VCC, Costa SF, Gomes MASM Gravidez recorrente na adolescência e vulnerabilidade social no Rio de Janeiro (RJ, Brasil): uma análise de dados do sistema de nascidos vivos. Ciênc Saúde Coletiva. 2011; 16:2485-93

21. Surita FGC, Suarez MBB, Siani S, Pinto e Silva JL. Factors associated with low birth weight among adolescents in the Brazil Southeast Region. Rev Bras Ginecol Obstet. 2011; 33:286-91.

22. Instituto Brasileiro de Geografia e Estatística (IBGE). Estatísticas do registro civil. Rio de Janeiro; 2007. v.34, p. 1-78.

23. Molina CR, González AE. Teenage pregnancy. Endocr Dev. 2012; 22:30231.

24. World Health Organization (WHO). Health in Italy in the21st century. [cited 2013 Jan 20]. Available from: http://www.euro.who.int/data/assets/pdf file/0020/127415/WA540G 1899HE.pdf.

25. Singh S, Darroch JE. Adolescent pregnancy and childbearing: Levels and trends in developed countries. Fam Plann Perspect. 2000; 32:14-23.

26. Fisher M, Lara-Torre E. Update on key topics in adolescent gynecology. J Pediatr Adolesc Gynecol. 2013; 26:51-7. 